
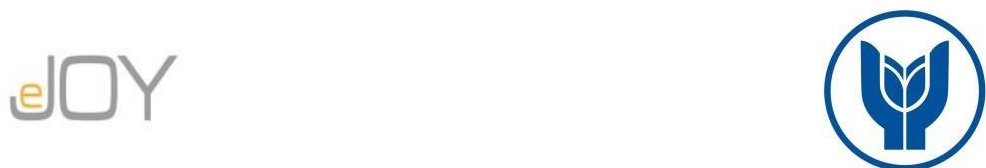

Bayır, M., Güvenoğlu, H. / Journal of Yasar University, 2020, 15/60, 971-986

\title{
Servetin Tüketim Üzerindeki Asimetrik Etkileri ${ }^{1}$
}

\section{The Asymmetric Effects of Wealth on Consumption}

\author{
Musa BAYIR, Bandırma Onyedi Eylül Üniversitesi Türkiye, musa.bayir@gmail.com \\ Orcid No: 0000-0002-6877-4032
}

Hüseyin GÜVENOĞLU, Bandırma Onyedi Eylül Üniversitesi, Türkiye, hguvenoglu@ bandirma.edu.tr

Orcid No: 0000-0002-5220-3657

\begin{abstract}
$\ddot{O ̈}_{z}$ Hanehalkı tüketim harcamaları ile ilgili kararlarını yalnızca cari gelirlerini değil, sahip oldukları serveti de göz önünde bulundurarak almaktadır. Bu durum iktisat literatüründe servet etkisi olarak isimlendirilmektedir. Teorik olarak, hane halkı servetinde yaşanan değişim tüketim harcamalarını etkilemektedir. Bu çerçevede, servet etkisinin varlı̆̆ının ekonomi üzerinde önemli etkilerinin olacă̆l ifade edilebilir. Diğer taraftan, Türkiye ekonomisinde son yıllarda konut ve finansal varlıkların fiyatlarında önemli dalgalanmalar yaşanmıştır. 2008 finansal krizi konut fiyatlarında yaşanan gelişmelerin toplam talep üzerindeki uyarıcı etkisinin önemini ortaya koymuştur. Bununla birlikte, yaşanan gelişmeler servetteki artış ve azalışın tüketim üzerindeki etkisinin aynı olmadığını göstermektedir. Bu doğrultuda, çalışmanın amacı konut ve finansal servetteki değişimin tüketim harcamaları üzerindeki asimetrik etkilerini ampirik olarak araştırmaktır. Çalışmada, iki ampirik model tahmin edilmektedir. Birincisinde, konut servetinin tüketim üzerindeki etkisi araştırılmaktadır. İkinci modelde ise finansal servetin tüketim üzerindeki etkisi araştırılmaktadır. Çalışmanın yöntemi NARDL'dir. Analizler 2011:Q1-2019:Q4 dönemini kapsamaktadır. Çalışmanın ampirik bulguları servet ve tüketim arasında asimetrik eşbütünleşme ilişkisi olduğunu göstermiştir. Uzun dönemde, konut servetindeki artışın tüketim üzerinde bir etkisi yoktur. Ancak, konut servetindeki \%1'lik bir azalma tüketimi \%0.32 düşürmektedir. Finansal servetteki değişimin tüketim üzerindeki etkisi ise hem artış hem azalış durumunda ortaya çıkmaktadır. Finansal servetteki $\% 1$ 'lik artış tüketimi \%0.18 artırırken, finansal servetteki \%1'lik düşme tüketimi \%0.21 azaltmaktadır. Sonuçlar birlikte değerlendirildiğinde, analiz döneminde servet etkisinin geçerli olduğu ifade edilebilir.
\end{abstract}

\section{Anahtar Sözcükler: Servet Etkisi, Tüketim, Konut Serveti, Finansal Servet, Asimetrik İlişki JEL Sinıflandırması: E21, D31, C32}

\begin{abstract}
Households make their decisions regarding their consumption expenditures by considering not only their current income but also their wealth. This relationship is termed as the wealth effect in the economic literature. Theoretically, the change in household wealth affects their consumption expenditures. In this context, it can be stated that the existence of the wealth effect will have important effects on the economy. On the other hand, the Turkish economy has experienced significant fluctuations in the prices of housing and financial assets in recent years. The 2008 financial crisis revealed the importance of the stimulating effect of housing prices on total demand. However, empirical evidence shows that the impact of increase and decrease in wealth on consumption is not the same. Accordingly, the study aims to empirically investigate the asymmetrical effects of the change in housing and financial wealth on consumption expenditures. In the study, we estimated two empirical models. Firstly, we investigated the effect of housing wealth on consumption. In the other model, we examined the impact of financial wealth on consumption. The empirical method of the study is NARDL. The analyses include between the 2011:Q1-2019:Q4 periods. The empirical results indicate that there is asymmetric cointegration relationship between wealth and consumption. In the long term, the increase in housing wealth has no effect on consumption. However, a $1 \%$ reduction in housing wealth lowers consumption by $0.32 \%$. The impact of the financial wealth on consumption occurs in both an increase and a decrease in financial wealth. While a $1 \%$ increase in financial wealth raises consumption by $0.18 \%$, a $1 \%$ decrease in financial wealth reduces consumption by $0.21 \%$. When the empirical results are evaluated together, it can be stated that the wealth effect is valid in the analysis period.
\end{abstract}

Keywords: Wealth Effect, Consumption, Housing Wealth, Financial Wealth, Asymmetric Relationship JEL Classification: E21, D31, C32

\footnotetext{
${ }^{1}$ Bu çalışma 26-27 Eylül 2019 tarihlerinde İstanbul'da düzenlenen "5. Uluslararası Ekonomi Yönetimi ve Pazar Araştırmaları Kongresi’nde sunulmustur.

Makale Geçmiși / Article History

Başvuru Tarihi / Date of Application

: 30 Nisan / April 2020

Kabul Tarihi / Acceptance Date

: 9 Temmuz / July 2020

(C) 2020 Journal of Yaşar University. Published by Yaşar University. Journal of Yaşar University is an open access journal.

There is no conflict of interest or ethical concern regarding this publication.
} 


\section{Giriş ve Kuramsal Çerçeve}

2000'li yıllardan itibaren ABD ekonomisinde konut sektöründe önemli bir canlılık ortaya çıkmıştır. Bununla birlikte, konut piyasalarında yaşanan olumlu gelişmeler zaman geçtikçe yerini konut fiyat balonu oluşumu endişesine bırakmıştır. Bunun üzerine, Amerikan Merkez Bankası (FED) 2000'li yıllardan sonra uyguladığı genişletici para politikasını sonlandırmıştır. $\mathrm{Bu}$ politika tercihi karşısında konut sektöründe yaşanan olumlu gelişmeler tersine dönmeye başlamıştır. Konut fiyatlarında yaşanan aşağı yönlü hareketle birlikte ABD ekonomisinde güçlü bir daralma ortaya çıkmış ve küresel krize dönüşen bir ekonomik konjonktüre girilmiştir. Ortaya çıkan ekonomik bunalımın talep daralmasına dayanması ve bunun konut fiyatlarında yaşanan tersine dönüşle ilişkilendirilmesi ekonomi literatüründe uzun süredir var olan servet etkisine ilişkin ilgiyi yeniden artırmıştır.

2008 finansal kriziyle mücadele sürecinde gelişmiş ülkeler önemli düzeyde likidite ortaya çıkaran genişletici politikalar uygulamıştır. Finansal kriz sürecinde bunun gelişmekte olan ülkeler üzerindeki etkisi gelişmekte olan ülkelere yönelik yabancı sermaye hareketlerini artırmak şeklinde olmuştur. Bununla birlikte, ekonomik krizin olumsuz etkilerini sınırlama çabası içerisinde olunması gelişmekte olan ülkelerde de politikacıların genişletici politikalar uygulamasına neden olmuştur. Bu politikalarla birlikte hem konut sektöründe hem de finansal sektörlerde önemli bir canlanma ortaya çıkmıştır. 2007 yılında konut sektörü ile ilgili gerçekleştirilen kanuni düzenlemelerinde etkisiyle bu sektörde 2011-2015 döneminde konut fiyatları hızlı bir şekilde artış göstermiştir (Güler, 2012). Aynı dönemde hisse senedi piyasasında da önemli bir canlanma yaşanmıştır. Bu dönemden sonra ise hem yerel ekonomik dinamiklerin etkisi, hem küresel likiditenin daralmasıyla birlikte her iki piyasada da bir daralma ortaya çıkmıştır. Reel olarak bakıldığında konut fiyat artışlarının 2017 yılından itibaren negatife döndüğü görülmektedir (TCMB, 2019). Bu gelişmeler, 2008 finansal krizine giden süreçte yaşanan gelişmeleri gündeme getirmiştir. Bu çerçevede, hanehalkının servet dağılımı içinde önemli bir yere sahip olan konut ve finansal varlıkların fiyatlarında yaşanan değişimlerin ekonomi üzerinde önemli etkilerinin olabileceği öngörülmektedir.

Teorik olarak bakıldığında, özel tüketim harcamaları toplam talep içerisinde önemli bir paya sahiptir. $\mathrm{Bu}$ çerçevede tüketim harcamalarında meydana gelebilecek artış veya azalışların ekonomiyi etkileyeceği söylenebilir. İktisadi literatüre göre tüketim harcamaları hem gelirin hem de servetin bir fonksiyonudur. Bu nedenle hanehalkının sahip olduğu servet portföyünde yer alan varlıkların değerlerinde yaşanacak değişikliğin tüketim harcamalarını da etkileyeceği düşünülmektedir. Sürekli gelirden bağımsız olarak tüketim harcamalarında meydana bu değişliğe "servet etkisi" denilmektedir. Servet etkisine ilişkin teorik temeller Keynezyen iktisadi düşünce çerçevesinde oluşmaya başlamıştır. İlk olarak Modigliani ve Brumberg (1954) yaşam döngüsü modelinde servet etkisinden söz etmiştir. Bu modelde hanehalkının gelirini hayatı boyunca en yüksek faydayı elde edeceği şekilde kullanacağı varsayımı söz konusudur. Buna göre bireyler elde ettikleri gelirin bir kısmını tasarruf ederek gelecek dönemlerde harcayabilmektedir. Tasarruf edilen gelir ise servetin temel kaynağıdır. $\mathrm{Bu}$ nedenle servette meydana gelecek artış veya azalışlar bireylerin tüketim harcamaları üzerinde etkili olmaktadır. Daha sonra Friedman (1957) sürekli gelir hipotezini ortaya koymuştur. $\mathrm{Bu}$ hipotezde, diğer tüketim modellerine tüketimin sadece gelirden etkilenmediğine ilişkin eleştiriler yöneltmiştir. Buna göre sürekli gelir ve geçici gelir ayrımı ortadan kaldırılıp hanehalkının tüketim kararlarını sürekli gelire göre aldığı ifade edilmiştir (Winkler, 2016). Servet etkisinin dikkate alındığı tüketim modellerinde tüketimin sürekli gelir, gelecek beklentisi, demografik unsurlar gibi ekonomik değişkenlerle birlikte hanehalk1 servetiyle açıklanmaya çalışıldığ 1 görülmektedir. Böylece hanehalkının servetinde meydana gelen artış ve azalışların diğer faktörler değişmese bile tüketimi değiştirebileceği belirtilmektedir. Servetin tüketimi etkilediği çeşitli aktarım kanalları bulunmaktadır. İlk aktarım kanalı teminat etkisi olarak isimlendirilmektedir. Teminat etkisi kanalı şu şekilde çalışmaktadır. Kredi piyasalarında asimetrik bilgi olduğu varsayımı söz konusudur. Asimetrik 
bilgi kredi piyasalarında ters seçim sorununa neden olmaktadır. Bu piyasa başarısızlığının önüne geçmek için teminat mekanizması kurulmuştur. İşte servette yaşanan değişim daha yüksek miktarda teminat sağlayacağı için aynı zamanda bireylerin kredi kullanım miktarını etkileyecektir. Başka bir ifadeyle, servette yaşanan değişim kişilerin borçlanma kapasitesini de değiştirmektedir. Nihai olarak, serveti artan bireylerin borçlanma imkânı artmakta ve daha fazla harcama olanağına sahip olunmaktadır (Aoki vd., 2004). İkinci aktarım mekanizması ihtiyati tasarruf kanalıdır. Hanehalkı elde ettikleri gelirin bir kısmını ihtiyati olarak tasarruf etmekte ve çeşitli servet unsurlarında değerlendirmektedir. Dolayısıyla varlıklarının değerinde yaşanan değişism bireylere daha fazla harcama imkânı sunmaktadır (Güler, 2012: 7-8). Son aktarım mekanizması güven kanalı olarak ifade edilmektedir. Buna göre, servette yaşanan artış ve azalış hanehalkının geleceğe bakışını değiştirmektedir. Buna bağlı olarak hanehalkı harcamalarını artırmakta veya azaltmaktadır (Helander, 2014: 23). Servetteki artışın tüketim harcamalarını artıracağı öngörüsünde bulunan bu üç görüşün dışında negatif servet etkisi kanalı olarak isimlendirilen bir mekanizma daha bulunmaktadır. Giuliodori (2005), Milcheva ve Sebastian (2010) çalışmalarında konut fiyatlarındaki artışın konut sahibi olmayan hanehalkı üzerinden de bir takım etkiler ortaya çıkaracağını ifade etmektedir. Buna göre, konut fiyatlarında yaşanan artış kira ücretlerini de artıracaktır. Artan kira harcamaları kirada oturan hane halkının harcanabilir gelirini düşürerek tüketim harcamalarını kısmasına neden olmaktadır. Bunun dışında artan konut fiyatlarının potansiyel konut alıcıları üzerinden ortaya çıkardığ 1 bir etki de söz konusudur. Buna göre, konut satın almak amacıyla birikim yapan hane halkının tasarrufları, konut fiyatlarındaki artışla birlikte nispi olarak daha değersiz hale gelecektir. Dolayısıyla hanehalkı daha fazla tasarruf etmek durumunda kalacaktır. Böylece harcanabilir gelirlerini ve tüketimlerini kısmak zorunda kalacaklardır. Negatif servet etkisinin geçerli olduğu durumda konut fiyatlarındaki gelişmeler tüketim harcamaları üzerinde negatif yönlü bir etki ortaya çıkarmaktadır.

Konut hanehalkının barınma ihtiyacını karşılamakla birlikte aynı zamanda bir yatırım aracı olma niteliğine sahiptir. Hanehalkının yatırım portföyüne bakıldığında geleneksel olarak büyük kısmı konuttan oluşmaktadır. Buna ek olarak konut servetinin hanehalkı arasındaki dağılımı nispeten homojendir. Bu iki özelliği konut servetindeki artış ve azalışların hanehalkı harcamaları üzerindeki genişletici ve daraltıcı etkisinin daha hissedilir olmasına yol açmaktadır. Servet portföyünün bir diğer önemli kısmı ise finansal varlıklardan oluşmaktadır. Gelişmekte olan ülkeler piyasa ekonomisini tam olarak işletemedikleri için finansal varlıklara yönelik yatırım konuta göre daha düşüktür. Bu nedenle finansal servetin hanehalkı arasındaki dağılımı daha heterojendir. Her iki servet unsurunun belirtilen özellikleri dikkate alındığında servet ve tüketim arasındaki ilişkiyi belirleyen çeşitli unsurlar bulunmaktadır. Bunlardan ilki servet sahiplerinin marjinal tüketim eğilimidir. Buna göre, geliri yüksek tüketicilerin marjinal tüketim eğilimi daha düşük olacaktır. Bu nedenle, bu kesimde servet etkisi daha küçük olacaktır. İkinci olarak, konut servetinde yaşanan değişimler finansal servetteki değişimlere kıyasla daha kalıcıdır. Bu çerçevede, konut servetinin tüketim üzerindeki etkisinin daha güçlü olacağı öngörülmektedir. Son olarak, konut servetinin nakde dönüşmesinde işlem maliyetleri yüksektir. Bu nedenle, söz konusu maliyetler konut servetinin tüketim üzerindeki etkisini azaltıcı bir etki ortaya çıkarmaktadır (Slacalek, 2009: 9-10).

Türkiye ekonomisinde, 2011 yılından sonraki dönemde konut ve finansal varlıklarının değerinde önemli dalgalanmalar yaşanmıştır. Bu noktadan hareketle konut ve hisse senedi piyasalarında yaşanan genişleme ve daralmaların servet etkisi kanalıyla tüketim üzerinde önemli etkilerinin olacağı ifade edilebilir. Bu durumun ampirik olarak araştırılması ekonomik açıdan oldukça önemlidir. Servet etkisine ilişkin elde edilecek ampirik sonuçların politikacılar açısından değerli bilgiler sunacağı söylenebilir. Böylece, hem makroekonomik tahminlerin daha tutarlı olması hem de daha uygun politika tasarımlarının yapılması sağlanacaktır. Bu çerçevede çalışmada, 2011-2019 döneminde Türkiye ekonomisinde konut servetinin ve finansal servetin tüketim harcamaları üzerindeki etkisinin ampirik olarak araştırılması 
amaçlanmaktadır. Bu kapsamda, ikinci bölümde literatür taramasına, üçüncü bölümde ampirik yöntem ve modele, dördüncü bölümde ampirik sonuçlara yer verilmektedir.

\section{Literatür Taraması}

Ampirik literatür incelendiğinde daha çok gelişmiş ülke ekonomilerini analiz eden çalışmaların olduğu görülmektedir. Bununla birlikte, gelişmekte olan ülkelerde servet etkisini araştıran çalışmalar da son dönemde artmıştır. Türkiye ekonomisine ilişkin ampirik literatür ise servete ilişkin veri eksikliğinden kaynaklı olarak oldukça sınırlıdır.

Gelişmiş ülkelerde servet etkisini araştıran çalışmalara bakıldığında genel olarak servetin tüketim üzerinde etkili olduğu sonucuna ulaşılmıştır. Bununla birlikte, finansal servetin ve konut servetinin nispi etkisinde döneme ve ülkelere göre farklılaşmalar söz konusudur. Slacalek (2009), çoğunluğunu $\mathrm{AB}$ ülkelerinin oluşturduğu 16 gelişmiş ülke ekonomisine ilişkin 1960-2000 yılları arasında farklı dönemler için gerçekleştirdiği analizde, finansal servetin ve konut servetinin tüketim üzerinde etkisi olduğu sonucuna ulaşmıştır. Bununla birlikte, Anglosakson ülkeleri ve Euro bölgesi dışında kalan ülkelerde servet etkisi daha zayıf bulunmuştur. $A B D$ ve İngiltere dişındaki ülke ekonomilerinde ise finansal servetin etkisi konut servetinden daha baskın bulunmuştur. Sousa (2009), Euro bölgesi ülkelerinde 19802007 döneminde gerçekleştirdiği analizde yine servet etkisinin varlığına ilişkin bulgular elde etmiştir. Buna ek olarak, tüketim üzerinde finansal servetin etkisinin nispeten büyük olduğunu ve konut servetinin etkisinin ise çok az olduğunu göstermiştir. Euro bölgesinden 10 ülke ekonomisinde 2000-2010 dönemini analiz eden Marzabal ve Junior (2016), benzer sonuçlar elde etmişler ve finansal servetin tüketime etkisini konut servetinden daha baskın bulmuşlardır. Bir başka çalışmada, Bassanetti ve Zollino (2010), İtalya ekonomisinde 19802008 dönemine ilişkin gerçekleştirdikleri analizde, konut ve finansal varlıklardan kaynaklanan servetin tüketim üzerinde pozitif bir etki oluşturduğu sonucuna ulaşmışlardır. Nispi etkiye bakıldığında ise, konuttan kaynaklanan servet etkisinin diğer varlıklara göre daha düşük olduğu görülmüştür. Barrell vd. (2015), İngiltere ve İtalya ekonomisinde konut serveti ve finansal servetin tüketim üzerindeki etkisini 1972-2012 döneminde analiz etmişlerdir. Analiz sonuçları, konut servetinin tüketimi İngiltere'de etkilerken İtalya'da etkilemediğini göstermiştir. Finansal servet ise her iki ülkede de toplam tüketimi pozitif ve önemli düzeyde etkilemektedir. Son olarak ise, İngiltere'de konut servetinin tüketim üzerindeki etkisi, İtalya'da ise finansal servetin tüketim üzerindeki etkisinin zaman içinde artış gösterdiği ifade edilmiştir. Bir diğer çalışmaya bakıldığında, Bonis ve Silvestrini (2012) ise 11 OECD ülkesinde 1997-2008 yılları arasında servetin tüketim üzerinde etkili olduğu sonucuna ulaşmışlardır. Hem finansal hem de reel servetin tüketim üzerinde pozitif etkiye sahip olduğunun bulunduğu analize göre, finansal servet tüketim üzerinde reel servetten daha etkili bulunmuştur. Benzer bir çalışmada, Shen vd. (2014) 14 OECD ülkesinde 1975-2011 döneminde hisse senedi ve konut servetinin tüketim üzerinde etkili olduğunu bulmuşlardır. Bununla birlikte, Bonis ve Silvestrini (2012) gibi hisse senedinin ortaya çıkardığ 1 servet etkisinin konutun ortaya çıkardığı servet etkisinden daha büyük olduğunu tespit etmişlerdir. Farklı olarak, 2000'li yıllardan sonra gayrimenkulden kaynaklanan servet etkisinin daha ağır bastığı ifade edilmiştir. Yukarıdaki çalışmalarda, 1960-2015 döneminde gelişmiş AB ve OECD ülkelerini dikkate alan analizlerde, genel olarak servet etkisinin varlığına ilişkin bulgular elde edilirken, finansal servetin konut servetine göre daha baskın olduğu sonucu elde edilmiştir. Case vd. (2005) ise 14 gelişmiş ülke ekonomisinde 1975-1999 dönemini kapsayan analizlerinde servet etkisinin varlığına ilişkin bulgular elde etseler de, konut servetinin tüketim üzerindeki etkisinin finansal servetten daha büyük olduğu sonucuna ulaşmışlardır. Başka bir çalışmada Coşkun vd. (2018) de, 11 gelişmiş ekonomide 1970-2015 dönemini analiz etmişler ve tüketimin finansal servetten ziyade konut serveti ile açıklandığı sonucuna ulaşmışlardır. Ek olarak, konut servetinin tüketim üzerinde pozitif ve önemli bir etkisi söz konusuyken hisse senedinden kaynaklanan servet ile tüketim arasında negatif ilişki olduğu 
vurgulanmıştır. Bertaut (2002), servet etkisinin etkinliğini ülkelere göre karşılaştırmalı olarak test etmiştir. Çalışmada konut ve finansal servetin ayrı ayrı veya birlikte ele alındığı veri setleriyle tahminler yapılmıştır. Analiz sonuçlarına göre, İngiltere, Kanada ve ABD'de servet etkisinin güçlü olduğu ifade edilmektedir. Bununla birlikte, Japonya'da servet etkisinin varlığına dair sonuçlar elde edilse de, 1990'ların ikinci yarısında tüketim üzerindeki nispi payının azaldığı ifade edilmektedir. Bununla birlikte, bazı küçük Avrupa ülkeleri dışında Avrupa ekonomilerinde ise servetin tüketim üzerindeki etkisi oldukça sinırlı bulunmuştur. Dvornak ve Kohler (2007), 1984-2001 dönemi için gerçekleştirdiği analizlerde Avustralya eyaletlerinden oluşan bir grupta hanehalkı servet değişiminin tüketim harcamaları üzerindeki etkisini araştırmışlardır. Hem konut hem de hisse senedi servetinin tüketim üzerinde önemli bir etkisi olduğu sonucu elde edilmiştir. Hamburg vd. (2008) Almanya ekonomisinde 19802003 döneminde servetin tüketim üzerindeki etkisini araştırmıştır. Buna göre, tüketim üzerinde servetin önemli bir etkisi olduğu sonucuna ulaşılmıştır.

Gelişmiş ülkelerde servet etkisini araştıran yukarıdaki çalışmalardan farklı olarak, ülkeleri finansal piyasaları banka bazlı ve piyasa bazlı olarak gruplayan ve buna göre analiz eden çalışmalar söz konusudur. Ludwig ve Slok (2004), 16 OECD ülkesinde 1960-2000 döneminde servet etkisini analiz etmişlerdir. Analiz sonuçları, uzun dönemde tüketimin hisse senedi fiyatlarındaki kalıcı değişikliklere verdiği tepkinin piyasa bazlı finansal sisteme sahip ülkelerde banka bazlı finansal sisteme sahip ülkelere kıyasla daha yüksek olduğunu göstermiştir. Bunun dışında, tüketim ve konut fiyatları arasında ise pozitif ilişski olduğu ve bu ilişkinin gücünün 1990'lı y1llardan sonra artış gösterdiği sonucu vurgulanmıştır. Winkler (2016) ise 14 gelişmiş ülkede 1995-2013 döneminde servet etkisini araştırmıştır. Kanada, Danimarka, Almanya, İtalya, Japonya ve ABD'de servet ile tüketim arasında eşbütünleşme ilişkisi olduğu sonucuna ulaşmıştır. Ayrıca, servet etkisinin tüketimin gelir esnekliği, servette yaşanan oynaklık ve gelir eşitsizliğinin yüksek olduğu ülkelerde daha düşük olduğu, iş koşullarının iyi ve krediye ulaşımın kolay olduğu ülkelerde ise daha büyük olduğu sonucu vurgulanmıştır.

Gelişmekte olan ülkelerle ilgili çalışmalara bakılırsa konut ve finansal servetin tüketime etkisinin araştırıldığ ç̧alışmalar olduğu gibi yalnızca konut veya finansal servetin etkisinin araştırıldığı çalışmalarda söz konusudur. Ciarlone (2011), Asya ve Avrupa'dan 17 gelişmekte olan ülke ekonomisinde 1995-2009 döneminde, reel ve finansal servetin tüketim üzerindeki etkisini araştırmıştır. Analiz sonuçları, reel ve finansal servetin göstergesi olarak kullanılan konut ve hisse senedinde yaşanan değişimin hane halkı tüketimini uzun dönemde pozitif olarak etkilediğini göstermiştir. Bununla birlikte, konut servetinin tüketime etkisi hisse senedinden daha büyük bulunmuştur. Asya ve Avrupa ülkeleri için ayrı ayrı gerçekleştirilen analizde ise Avrupa ülkelerinde konut fiyatlarının tüketim üzerindeki etkisi daha yüksek bulunmuştur. Peltonen vd. (2012), 14 gelişmekte olan ülkede 1975-2008 döneminde servet etkisini araştırdığı çalışmasında benzer sonuçlar elde etmişlerdir. Buna göre, konut serveti finansal piyasaların gelişmediği ve düşük gelire sahip ülkelerde tüketim üzerinde daha fazla etkili olurken, finansal servet ise finansal piyasaların daha çok geliştiği ülkelerde tüketim üzerinde daha etkili olmaktadır. Bunun dışında, Latin Amerika ülkelerinde hem hisse senedi hem de konut servetinin tüketim üzerindeki etkisinin küçük olduğu, Asya ülkelerinde ise konut servetinin tüketim üzerindeki etkisinde son yıllarda artış yaşandığı sonucu elde edilmiştir. Hane halkı servetinin tüketim üzerindeki etkisini, Athanassiou ve Tsouma (2017) Yunanistan ekonomisinde 2000-2015 döneminde, Georgakopoulos (2019) Malta ekonomisinde 2017 yılına ait hane halk1 finans ve tüketim anketinden hareketle analiz etmiştir. Analiz sonuçları, hem finansal servet hem de konut servetinin tüketimi pozitif etkilediğini göstermiştir. Bununla birlikte, konut servetinin tüketim üzerindeki etkisinin finansal servetten daha belirgin olduğu tespit edilmiştir. Hui vd. (2012), konut serveti ve finansal servetin tüketim üzerindeki etkisini, Hong Kong ekonomisinde 1981-2010 dönemi için analiz etmişlerdir. Analiz sonuçları, hem konut hem de finansal servetin tüketim üzerinde önemli bir etkisi olduğunu göstermiştir. Kengne vd. (2012), Güney Afrika ekonomisinde 
1996-2010 döneminde yalnızca konut fiyatlarının tüketim üzerindeki etkisini analiz etmişler ve konut fiyatlarındaki artışın tüketim üzerinde önemli bir artış oluşturduğu sonucuna ulaşmışlardır. Analiz sonuçları, konut fiyatlarındaki negatif şokun tüketim üzerindeki etkisinin ise önemli olmayan düzeyde ve negatif olduğunu göstermiştir. Singh (2012), Hindistan ekonomisinde 1996-2010 döneminde varlık piyasalarından kaynaklanan servetin tüketim üzerinde etkisini analiz etmiştir. Analiz sonuçları, Hindistan ekonomisinde varlık piyasalarının tüketim üzerindeki servet etkisinin nispeten küçük olduğunu göstermiştir. Son olarak, Sonje vd. (2014), 30 gelişmiş ve gelişmekte olan ülke ekonomisinde hisse senedi ve konut servetinin tüketim üzerindeki etkisini araştırmışlardır. Analiz sonuçları, hisse senedinin ortaya çıkardığı servet etkisinin gelişmiş ülkelerde güçlü, gelişmekte olan ülkelerde ise zayıf olduğunu göstermiştir. Konutun ortaya çıkardığı servet etkisi ise gelişmekte olan ülkelerde güçlü bulunmuştur.

Literatürde servetin tüketim üzerindeki asimetrik etkilerini araştıran az sayıda çalışma da bulunmaktadır. Apergis ve Miller (2004) 1957-2002 döneminde, ABD ekonomisinde finansal servetteki değişimin tüketim harcamaları üzerindeki asimetrik etkilerini araştırmıştır. Analiz sonuçları asimetrik etkilerin söz konusu olduğunu ve finansal servetteki negatif yönlü değişimin tüketim üzerindeki etkisinin pozitif yönlü değişimlerin etkisine kıyasla daha baskın olduğu sonucuna ulaşılmıştır. Marquez vd. (2013) 1976-2009 döneminde İngiltere ekonomisi için benzer bir yöntem kullanmıştır. Analiz sonuçlarına göre, konut servetindeki artışların tüketim harcamalarını etkilerken azalışların herhangi bir etkisi olmadığı sonucu elde edilmiştir. Diğer tarafta, finansal servetteki pozitif değişimler etkisiz bulunurken negatif değişimler etkili bulunmuştur. Wülfers (2017) ise 1993-2017 döneminde İsveç ekonomisini incelemiştir. Hem konut hem de finansal servetteki pozitif ve negatif şokların tüketime etkisi farklılaşmaktadır. Bununla birlikte, uzun dönemde konut ve finansal servetin tüketim harcamaları üzerinde pozitif yönlü bir etkiye sahip olduğu ifade edilmektedir.

Türkiye ekonomisinde servet etkisinin araştırıldığı çalışma sayısı oldukça sınırlıdır. Bunlardan, Akkoyunlu (2002), 1962-1994 döneminde servet ve tüketim arasındaki ilişkiyi araştırmıştır. Analiz sonuçları, konut servetinin tüketim üzerinde etkili olduğunu ve bu etkinin finansal servetin tüketim üzerindeki etkisinden küçük olduğunu göstermiştir. Binay ve Salman (2008), servet etkisini 1960-2005 dönemi için araştırmışlardır. Analiz sonuçları, konut servetinin tüketim üzerinde önemli bir etkiye sahip olduğunu göstermiştir. Bununla birlikte, finansal servetin tüketim üzerinde anlamlı bir etkisi bulunamamıştır. Akın (2008), servet etkisinin tüketime etkisini 1987-2006 dönemi için analiz etmiştir. Analiz sonuçları, uzun dönemde konut servetinin dayanıklı tüketim üzerinde etkisi olmadığını, dayanıklı olmayan tüketim üzerinde pozitif bir etkiye sahip olduğunu göstermiştir. Hisse senedinden kaynaklanan servetin ise dayanaklı olmayan malların tüketimi üzerinde etkisizken dayanıklı malların tüketiminde etkili olduğunu göstermiştir. Kısa dönemde ise, konut serveti dayanıklı olmayan mallar üzerinde negatif etkiliyken, hisse senedi serveti her iki tüketim üzerinde pozitif etkiye sahip bulunmuştur. Özer ve Tang (2009), 1987-2007 dönemi için bir analiz gerçekleştirmişlerdir. Buna göre, finansal servetin ve konut servetinin tüketim üzerinde pozitif yönde bir etki ortaya çıkardığı sonucu elde edilmiştir. Güler (2012) ise 1991-2011 dönemi için analiz yapmıştır. Analiz sonuçları, konut servetinin tüketime etkisinin 2001 ekonomik krizinden sonra artığını ve harcanabilir gelirin tüketim üzerindeki etkisinin ise azaldığını göstermiştir. Aynı çalışmada, finansal servetin tüketime etkisine ilişkin ise 2001 krizi öncesinde pozitif yönlü bir ilişki varken, finansal kriz sonrasında bu ilişkinin önemsizleştiği sonucu vurgulanmıştır. Ceritoğlu (2017), 2003-2014 döneminde konut fiyat değişikliklerinin tüketime etkisini araştırmıştır. Buna göre, konut fiyat değişikliklerinin tüketim üzerinde pozitif etkili olduğu sonucuna ulaşılmıştır. Bu etki beklendiği şekilde konut sahiplerinin olduğu gruplar için daha güçlüdür. Ancak ödenmemiş konut borcunun servet etkisini düşürdüğü sonucu vurgulanmaktadır. Buna ek olarak, etkinin büyüklüğü genç gruplardan yaşlı gruplara doğru artış göstermektedir. Alp ve Seven (2019) ise 1998-2016 dönemine ilişkin bir analiz yapmışlardır. Burada, hisse senedinin ve konut servetinin tüketim üzerindeki 
etkisi araştırılmıştır. Çalışmada, konut servetinin tüketimi artırdığı, hisse senedi servetinin ise düşürdüğü sonucuna ulaşılmıştır.

\section{Yöntem ve Veri Seti}

\subsection{Yöntem}

Türkiye ekonomisinde servet etkisinin varlığının ampirik olarak araştırıldığı çalışmada iki ekonometrik model oluşturulmuştur. İlk modelde, konut servetindeki değişikliğin tüketim harcamaları üzerindeki etkisi araştırılmaktadır. İkinci model ise finansal servetin tüketim harcamaları üzerindeki etkisinin tahmininde kullanılmaktadır. Her iki modelde de bağımlı değişken tüketim harcamalarıdır. Bağımsız değişkenler ise, ilk modelde konut servetindeki değişimin göstergesi olan konut fiyatları; ikinci modelde finansal servetin göstergesi olan hisse senedi fiyatlarıdır. Hanehalkı servetindeki değişimin tüketim harcamaları üzerindeki etkisinin yönü teorik olarak açıklanmıştır. Buna göre, teminat, ihtiyati tasarruf ve güven kanalı üzerinden pozitif yönlü etki ortaya çıkmaktadır. Bununla birlikte, konut fiyatlarındaki değişime özgü olarak negatif servet etkisi de söz konusudur. Negatif servet etkisi konut servetinde yaşanan değişimin tüketim harcamaları üzerinde ters yönlü bir etki ortaya çıkmasına neden olabilmektedir.

$\mathrm{Bu}$ çerçevede çalışmanın yöntemi olarak Shin vd. (2014) tarafından geliştirilen NARDL (nonlinear ARDL) yaklaşımı kullanılmaktadır. Bu yöntem, Pesaran vd. (2001) tarafından ortaya konulan ARDL yaklaşımını temel almaktadır. ARDL yaklaşımı diğer eşbütünleşme testlerine kıyasla birçok üstünlüğe sahiptir. Öncelikle, diğer eşbütünleşme testlerinde olduğu gibi serilerin aynı dereceden durağan olmasına gerek yoktur. Gerçekleştirilecek tahminlerde kullanılacak seriler, I(2) olmamak kaydiyla, I(0) veya I(1) olarak kullanılabilmektedir. Bununla birlikte, küçük ve sınırlı sayıda örneklemlerle gerçekleştirilen analizlerde etkin ve tutarlı tahmin sonuçları elde edilebilmektedir. Sunduğu bu avantajlar, değişkenler arasındaki ilişkilerin araştırılmasında ARDL yaklaşımının kullanımını oldukça yaygınlaştırmıştır. Diğer taraftan, literatürde iktisadi değişkenler arasındaki ilişkilerin doğrusal olmadığına dair uzunca zamandır süregelen bir tartışma söz konusudur. Bu tartışmalar, ekonomide bulunan fiyat ve ücret katılıkları, asimetrik bilgi vb. piyasa aksaklıklarından hareketle sürdürülmektedir. $\mathrm{Bu}$ durum ekonomik değişkenlerin bir başka değişkende yaşanan pozitif ve negatif şoklara aynı tepkiyi vermeyeceği görüşünü ortaya çıkarmaktadır. Çalışmadan hareketle, servetteki artışın tüketim harcamaları üzerindeki etkisinin servetteki azalışın tüketim harcamaları üzerindeki etkisinden farklılaşabileceğini ifade edebiliriz. Bu durumda, ekonometrik analizlerde doğrusal modellerle gerçekleştirilecek tahminler, servetin tüketim harcamaları üzerindeki etkisini doğru tespit etmeyi engelleyecektir. Bu çerçevede, çalışmada servetteki artış ve azalışın tüketim harcamaları üzerindeki etkisinin ayrı ayrı tahmin edilmesine imkân sağlayan NARDL yöntemi benimsenmektedir. Bu yöntemde, Pesaran vd. (2001) tarafindan geliştirilen ARDL yaklaşımından farklı olarak değişkenler arasındaki asimetrik ilişki dikkate alınmaktadır. Buna göre, bağımsız değişkenlerdeki pozitif ve negatif şokların bağımlı değişken üzerindeki etkisi birbirinden ayrı olarak incelenmektedir (Shin vd., 2014).

NARDL yönteminde değişkenler arasındaki asimetrik uzun dönem ilişki (1) numaralı denklemde yer alan asimetrik eşbütünleşme regresyonu ile araştırılmaktadır.

$$
\begin{aligned}
& y_{t}=\beta^{+} x_{t}^{+}+\beta^{-} x_{t}^{-}+u_{t} \\
& x_{t}=x_{0}+x_{t}^{+}-x_{t}^{-} \\
& x_{t}^{+}=\sum_{i=1}^{t} \Delta x_{t}^{+}=\sum_{i=1}^{t} \max \left(\Delta x_{i}, 0\right) \\
& x_{t}^{-}=\sum_{i=1}^{t} \Delta x_{t}^{-}=\sum_{i=1}^{t} \max \left(\Delta x_{i}, 0\right)
\end{aligned}
$$

Burada $y_{t}$ bağımlı değişken, $u_{t}$ hata terimi ve $\beta^{+}$ve $\beta^{-}$asimetrik uzun dönem katsayılarını göstermektedir. (2) numaralı denklemde, $x_{t}^{+}$ve $x_{t}^{-}$bağımsız değişskendeki pozitif ve negatif kısmi toplamları ifade ederken, $x_{0}$ terimi bağımsız değişkenin ilk gözlem değerini 
belirtmektedir. (3) ve (4) numaralı denklemde ise, asimetrik pozitif ve negatif kısmi toplam süreçleri tanımlanmaktadır.

Çalışmanın doğrusal modelleri denklem (5) ve (6)'da tanımlanmaktadır. Burada, tüketim $_{t}$ bağımlı değişkeni, $k s_{t}$ ve $f s_{t}$ bağımsız değişkeni göstermektedir.

$$
\begin{aligned}
& \text { tüketim }_{t}=\alpha_{0}+\alpha_{1} k s_{t}+\varepsilon_{t} \\
& \text { tüketim }_{t}=\alpha_{0}+\alpha_{1} f s_{t}+\varepsilon_{t}
\end{aligned}
$$

NARDL yönteminde asimetrik ilişkilerin tespit edilmesi amacıyla (5) ve (6) numaralı denklemde gösterilen doğrusal model, doğrusal olmayan bir forma dönüştürülür. (7) ve (8) numaralı denklemlerde tahmin edilecek modelin doğrusal olmayan formları gösterilmektedir.

$$
\begin{aligned}
& \Delta \text { tüketim }_{t}=\alpha_{0}+\rho \text { tüketim }_{t-1}+\theta^{+} k s_{t-1}^{+}+\theta^{-} k s_{t-1}^{-}+\sum_{i=1}^{p-1} \mu \Delta \text { tüketim }_{t-i}+ \\
& \sum_{i=0}^{q}\left(\pi_{i}^{+} \Delta k s_{t-i}^{+}+\pi_{i}^{-} \Delta k s_{t-i}^{-}\right)+\varepsilon_{t} \\
& \Delta \text { tüketim }_{t}=\alpha_{0}+\rho \text { tüketim }{ }_{t-1}+\theta^{+} f s_{t-1}^{+}+\theta^{-} f s_{t-1}^{-}+\sum_{i=1}^{p-1} \mu \Delta \text { tüketim }_{t-i}+ \\
& \sum_{i=0}^{q}\left(\pi_{i}^{+} \Delta f s_{t-i}^{+}+\pi_{i}^{-} \Delta f s_{t-i}^{-}\right)+\varepsilon_{t}
\end{aligned}
$$

Denklem (7) ve (8)'de $\Delta$ tüketim ${ }_{\mathrm{t}}$ bağımlı değişkendir. $k s^{+}$ve $k s^{-}$tüketim harcamaları üzerinde konut servetinin pozitif ve negatif şoklarını, $f s^{+}$ve $f s^{-}$tüketim harcamaları üzerinde finansal servetin pozitif ve negatif şoklarını göstermektedir. $\mathrm{p}$ ve $\mathrm{q}$ ise optimum gecikme uzunluklarını ifade etmektedir. Asimetrik uzun dönem katsayıları $\beta_{1}=-\frac{\theta^{+}}{\rho}$ ve $\beta_{2}=$ $-\frac{\theta^{-}}{\rho}$ formülüyle hesaplanmaktadır. $\sum_{i=0}^{q} \pi_{i}^{+}$ve $\sum_{i=0}^{q} \pi_{i}^{-}$ise tüketim harcamaları üzerinde pozitif ve negatif şokların kısa dönem etkisini ölçmek için kullanılmaktadır (Shin vd., 2014).

Analiz kısmında ilk olarak serilerin durağanlık dereceleri araştırılmaktadır. Bu amaçla birim kök testleri kullanılmaktadır. NARDL yönteminde de ARDL'de olduğu gibi serilerin ikinci farkında durağan olmaması gerekmektedir. Bunun dışında, düzey halde veya birinci farkında durağan olan seriler analizde kullanılabilmektedir. Daha sonraki aşamada otokorelasyon sorunu bulunmayan optimum gecikme uzunluğu belirlenerek (7) ve (8) numaralı model OLS tekniğiyle tahmin edilmektedir. Üçüncü aşamada, değişkenler arasındaki eşbütünleşme ilişkisini araştırmak amacıyla sınır (bound) testi gerçekleştirilmektedir. Sınır testi, Pesaran vd. (2001)'deki gibi uygulanarak $\rho=\theta^{+}=\theta^{-}=0$ hipotezi sinanmaktadır. Dördüncü aşamada, asimetrik ilişkinin varlığını tespit etmek amaciyla Wald testi yapılmaktadır. Buna göre, uzun dönem $\left(\beta_{1}=\beta_{2}\right)$ ve k1sa dönem $\left(\pi_{i}^{+}=\pi_{i}^{-}\right)$asimetrisi araştırılmaktadır. Wald testinde boş hipotezin reddedilmesi değişkenler arasında asimetrik ilişki olduğunu ifade etmektedir. Asimetrik ilişkinin varlığının ortaya konulmasının ardından kısa ve uzun dönemli tahminler gerçekleştirilmektedir.

\subsection{Veri Seti}

Ampirik modelde, konut serveti ve finansal servetin tüketim harcamaları üzerindeki etkisi araştırılmaktadır. Modelde kullanılan değişkenlere ilişkin açıklayıcı bilgiler tablo 1 'de yer almaktadır. Çalışmada, bağımlı değişken olarak yer alan tüketim harcamalarının göstergesi olarak hane halkı tüketim harcamaları $(2009=100)$ kullanılmıştır. Bu değişken mevsimsel ve takvim etkisinden arındırılmış olarak TÜİK veri tabanından elde edilmiştir. İlk modelde bağımsız değişken olan konut servetinin göstergesi olarak konut fiyat endeksi $(2017=100)$ kullanılmıştır. $\mathrm{Bu}$ değişkene ilişkin veri seti $\mathrm{TCMB}$ veri tabanından indirilmiştir. İkinci modelde bağımsız değişken olan finansal servetin göstergesi olarak ise hisse senedi fiyatları kullanılmıştır. Analizde bu değişkenin göstergesi olarak BİST100 endeksi tercih edilmiştir. $\mathrm{Bu}$ değişkene ilişkin veri setine ise Borsa İstanbul veri tabanından ulaşılmıştır. Analizlerde kullanılan bütün değişkenler oran olarak kullanılmıştır. Çalışmanın analiz dönemi 2011:Q12019:Q4 dönemini kapsamaktadır. Analiz dönemi belirlenirken verilerin ulaş1labilirliği göz önüne alınmıştır. 
Tablo 1. Değiş̧kenlere İlişkin Açıklamalar

\begin{tabular}{|c|c|c|}
\hline Değişken & Açılklama & Kaynak \\
\hline $\begin{array}{l}\text { Tüketim Harcamalarındaki } \\
\text { Değișim Oranı (tüketim) }\end{array}$ & $\begin{array}{l}\text { Özel Tüketim } \quad \text { Harcamaları } \\
(2009=100)\end{array}$ & TÜİK \\
\hline $\begin{array}{l}\text { Konut Servetindeki Değişism } \\
\text { Oranı (ks) }\end{array}$ & Konut Fiyat Endeksi $(2017=100)$ & CBRT \\
\hline $\begin{array}{l}\text { Konut Serveti Artış Oranı } \\
\left(\mathrm{ks}^{+}\right)\end{array}$ & $\begin{array}{l}\text { Konut Fiyatlarındaki } \\
\text { Değişiklikler }\end{array}$ & \\
\hline $\begin{array}{l}\text { Konut Serveti Azalış Oranı } \\
\left(\mathrm{ks}^{-}\right)\end{array}$ & $\begin{array}{l}\text { Konut Fiyatlarındaki Negatif } \\
\text { Değişiklikler }\end{array}$ & \\
\hline $\begin{array}{l}\text { Finansal Servetteki Değişimim } \\
\text { Oranı (fs) }\end{array}$ & BİST 100 & BİST \\
\hline $\begin{array}{l}\text { Finansal Servet Artış Oranı } \\
\left(\mathrm{fs}^{+}\right)\end{array}$ & $\begin{array}{l}\text { BİST 100'deki } \\
\text { Değişiklikler }\end{array}$ & \\
\hline $\begin{array}{lll}\text { Finansal } & \text { Servet } & \text { Azalış } \\
\text { Oranı }\left(\mathrm{fs}^{-}\right) & & \\
\end{array}$ & $\begin{array}{l}\text { BİST 100’deki } \\
\text { Değişiklikler }\end{array}$ & \\
\hline
\end{tabular}

Analizlerde kullanılan değişkenlere ilişkin grafikler şekil 1'de yer almaktadır. Grafiklerden hareketle analiz dönemi içinde hem servette hem de tüketim harcamalarında önemli dalgalanmaların yaşandığı ifade edilebilmektedir.

Tüketim Harcamaları

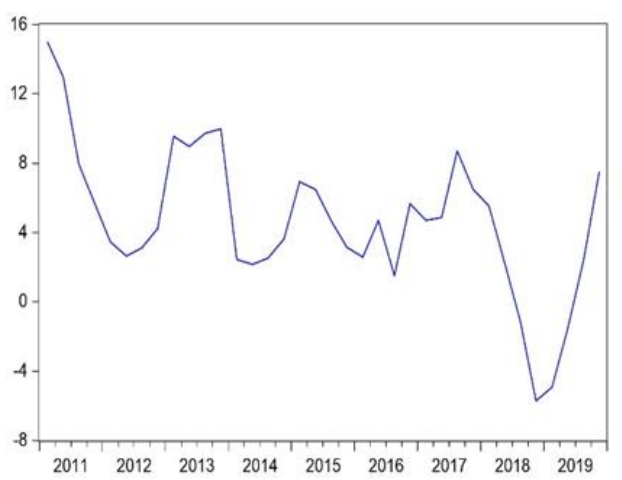

Konut Fiyatları

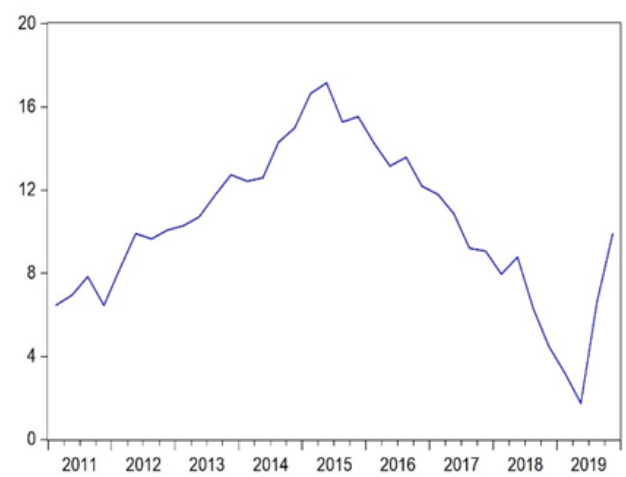

BİST 100

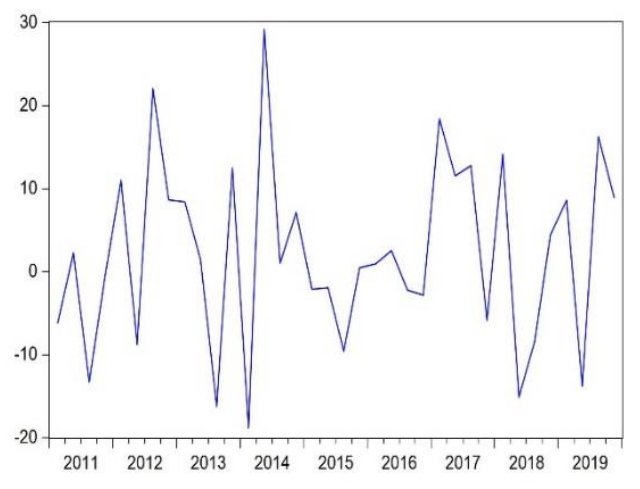

Şekil 1. Değişkenlerin Grafikleri

NARDL tahminine geçmeden önce, bu bölümde değişkenlerin durağanlık düzeyleri araştırılmaktadır. Bu doğrultuda gerçekleştirilen ADF ve PP birim kök testi sonuçları tablo 
2'de yer almaktadır. Her iki birim kök testi gerçekleştirilirken de hem sabit hem de sabit+trend içeren model tahminleri kullanılmıştır. Hem ADF hem de PP birim kök testinde bütün değişkenler birinci farkı alındığında durağan bulunmuştur. Buna göre, bütün değişkenler I(1)'de durağandır ve I(2) olan değişken bulunmamaktadır. Dolayısıyla NARDL tahminlerinin gerçekleştirilmesi açısından gerekli ön şart gerçekleşmiş olmaktadır.

Tablo 2. ADF ve PP Birim Kök Testi Sonuçları

\begin{tabular}{|c|c|c|c|c|}
\hline \multicolumn{5}{|c|}{ Augmented Dickey-Fuller (ADF) } \\
\hline \multirow{2}{*}{ Değişkenler } & \multicolumn{2}{|c|}{ (Düzey) } & \multicolumn{2}{|c|}{ (Birinci Fark) } \\
\hline & sabit & sabit-trend & sabit & sabit-trend \\
\hline tüketim & $-2.182(4)$ & $-6.179 * * *(3)$ & $-5.669 * * *(3)$ & $-5.578 * * *(3)$ \\
\hline $\mathrm{ks}^{+}$ & $0.074(1)$ & $-2.065(1)$ & $-3.155 * *(0)$ & $-3.202 * *(0)$ \\
\hline $\mathrm{ks}^{-}$ & $2.084(0)$ & $-6.157(4)$ & $-4.934 * * *(0)$ & $-5.849 * * *(0)$ \\
\hline $\mathrm{fs}^{+}$ & $-0.875(1)$ & $-2.560(0)$ & $-7.870 * * *(0)$ & $-7.776 * * *(0)$ \\
\hline $\mathrm{fs}^{-}$ & $-0.873(2)$ & $-1.810(2)$ & $-3.402 * *(1)$ & $-3.294 * *(1)$ \\
\hline \multicolumn{5}{|c|}{ Phillips-Perron $(P P)$} \\
\hline \multirow{2}{*}{ Değişkenler } & \multicolumn{2}{|c|}{ (Düzey) } & \multicolumn{2}{|c|}{ (Birinci Fark) } \\
\hline & sabit & sabit-trend & sabit & sabit-trend \\
\hline tüketim & $-2.207(1)$ & $-2.679(1)$ & $-4.484 * * *(2)$ & $-4.418 * * *(2)$ \\
\hline $\mathrm{ks}^{+}$ & $-0.098(1)$ & $-1.247(0)$ & $-3.209 * *(1)$ & $-3.376 * *(1)$ \\
\hline $\mathrm{ks}^{-}$ & $2.085(2)$ & $-0.760(1)$ & $-5.140 * * *(4)$ & $-5.849 * * *(0)$ \\
\hline $\mathrm{fs}^{+}$ & $-0.699(4)$ & $-2.430(1)$ & $-7.767 * * *(2)$ & $-7.692 * * *(2)$ \\
\hline $\mathrm{fs}^{-}$ & $-0.946(5)$ & $-1.9746(1)$ & $-8.626 * * *(2)$ & $-8.553 * * *(2)$ \\
\hline
\end{tabular}

Not: $* * *$ ve ${ }^{* *}$ sırasıyla $\% 1$ ve $\% 5$ anlamlılık düzeyinde serilerin durağanlığını ifade etmektedir. Parantez içindeki rakamlar gecikme uzunluğunu ifade etmektedir.

\section{Ampirik Analiz Sonuçları}

Konut ve finansal servetin tüketim harcamaları üzerindeki etkisinin araştırıldığı ekonometrik model tahminleri, NARDL yöntemi kullanılarak gerçekleştirilmiştir. Böylece hanehalk1 servetinde yaşanan değişimin tüketim harcamaları üzerindeki asimetrik etkileri ortaya konulmaya çalışılmıştır. Tablo 3 konut servetinin tüketim harcamaları üzerindeki etkisine ilişkin NARDL tahmin sonuçlarını göstermektedir. İlk olarak, değişkenler arasındaki asimetrik eşbütünleşme ilişkisi sınır testi ile araştırılmaktadır ${ }^{2}$. Buna göre, $\mathrm{F}$ istatistik değeri 4.686 olarak hesaplanmıştır. Bu değer, Pesaran vd. (2001) tarafından hesaplanan tablo üst değerini (3.87) aştığı için değişkenler arasında \%5 anlamlılık düzeyinde asimetrik eşbütünleşme ilişkisi olduğuna karar verilmektedir. İkinci aşamada, değişkenler arasındaki asimetrik ilişkinin varlığını araştırmak amacıyla Wald testi uygulanmaktadır. Elde edilen uzun dönem Wald istatistik değeri (13.490) ve kısa dönem Wald istatistik değeri (12.490) tablo değerlerinden büyüktür. Buradan hareketle, tahmin edilen uzun ve kısa dönem NARDL sonuçlarının geçerli olduğuna karar verilmektedir. Tablo 3-Panel C NARDL modeli tahminlerine ilişkin tanısal test istatistiklerini sunmaktadır. Buna göre, modelin açıklayıcılık gücü $\left(\mathrm{R}^{2}\right.$ ve Düzeltilmiş $\left.\mathrm{R}^{2}\right)$ yeterli görülmektedir. Otokorelasyon ve değişen varyans sorununu araştırmak amaciyla gerçekleştirilen testlerin sonucu tahminlerde otokorelasyon ve değişen varyans sorunu olmadığını göstermektedir. Hata terimlerinin normal dağılımını araştırmak için gerçekleştirdiğimiz teste göre, hata terimlerinin normal dağıldığ 1 sonucuna ulaşılmaktadır. Son olarak modelde spefikasyon hatası bulunup bulunmadığının test edildiği Ramsey-Reset testi sonucu modelin doğru kurulduğunu göstermektedir.

\footnotetext{
${ }^{2}$ Doğrusal modeller kullanılarak gerçekleştirilen tahminlerden hareketle de sınır testi gerçekleştirilmiştir. Buna göre, F istatistik değeri 1.939 çıkmıştır. Sonuç olarak, doğrusal model tahmininde değişkenler arasında eşbütünleşme ilişkisi olmadı̆̆ı sonucuna ulaşılmıştır.
} 
Tablo 3-Panel B hesaplanan uzun dönem katsayılarını göstermektedir. Konut servetindeki artışın tüketim harcamaları üzerindeki etkisini gösteren $\mathrm{L}_{\mathrm{ks}^{+}}$katsayısı istatistiksel açıdan anlamsızdır. Dolayısıyla konut servetindeki artışın uzun dönemde tüketim harcamalarını etkilemediği ifade edilebilir. Konut servetindeki azalışın tüketim harcamaları üzerindeki etkisini gösteren $\mathrm{L}_{\mathrm{ks}^{-}}$katsayısı ise istatistiksel açıdan anlamlıdır. Buna göre, uzun dönemde konut servetindeki \%1'lik azalışın tüketim harcamaları üzerinde $\% 0.32$ oranında bir azalma ortaya çıkardığı söylenebilir. Hata düzeltme modeli tahmin sonuçlarına bakılırsa, hata düzeltme katsayısı (ect $\mathrm{t}-1_{1}$ ) negatif ve istatistiksel açıdan anlamlıdır. Bu sonuç, uzun dönem denge değerinden sapma oluşturacak bir şokun \%94 gibi bir hızla dengeye geldiğini göstermektedir. Bununla birlikte, hata düzeltme mekanizması çalışmaktadır.

Tablo 3. Konut Servetinin Tüketim Harcamalarına Etkisi NARDL Tahmin Sonuçları

\begin{tabular}{|c|c|c|c|}
\hline \multicolumn{4}{|c|}{ Panel A: Hata Düzeltme Modeli Tahmin Sonuçları } \\
\hline Değişken & Katsayı & Std. Hata & t ist. \\
\hline$\Delta$ tüketim $_{t-1}$ & 0.522 & 0.15 & $3.35 * * *$ \\
\hline$\Delta$ tüketim $_{t-2}$ & 0.598 & 0.14 & $4.25 * * *$ \\
\hline$\Delta$ tüketim $_{t-3}$ & 0.483 & 0.15 & $3.12 * * *$ \\
\hline$\Delta$ tüketim $_{\mathrm{t}-4}$ & -0.327 & 0.14 & $-2.19 * *$ \\
\hline$\Delta \mathbf{k s}^{+}$ & 0.306 & 0.29 & 1.03 \\
\hline$\Delta \mathbf{k s}_{\mathrm{t}-1}^{+}$ & 0.155 & 0.32 & 0.47 \\
\hline$\Delta \mathbf{k s}_{\mathbf{t}-2}^{+}$ & -2.245 & 0.46 & $-4.79 * * *$ \\
\hline$\Delta \mathbf{k s}^{-}$ & -0.551 & 0.35 & -1.53 \\
\hline ect $_{t-1}$ & -0.94 & 0.20 & $-4.64 * * *$ \\
\hline \multicolumn{4}{|c|}{ Panel B: Uzun Dönem Katsayıları } \\
\hline $\mathbf{L}_{\mathbf{k s}^{+}}$ & -0.235 & 0.15 & -1.56 \\
\hline $\mathbf{L}_{\mathbf{k s}^{-}}$ & 0.320 & 0.12 & $2.58 * *$ \\
\hline $\mathrm{c}$ & 9.442 & 1.333 & $7.07 * * *$ \\
\hline \multicolumn{4}{|c|}{ Panel C: Tanımlayıcı Istatistikler } \\
\hline $\mathbf{R}^{2}$ & 0.86 & FPSS $_{\text {P }}$ & $4.686 * *$ \\
\hline Düzeltilmiș $\mathbf{R}^{2}$ & 0.79 & $\mathbf{W}_{\mathrm{LR}}$ & $13.490 * * *$ \\
\hline$\chi_{\mathrm{BG}}^{2}$ & $0.156[0.855]$ & $\mathbf{W}_{\mathbf{S R}}$ & $12.490 * * *$ \\
\hline$\chi_{\text {RAMSEY }}^{2}$ & $4.015[0.059]$ & CUSUM & Durağan \\
\hline$\chi_{\mathrm{BPG}}^{2}$ & $0.960[0.508]$ & CUSUM $^{2}$ & Durağan \\
\hline$\chi_{\mathrm{NOR}}^{2}$ & $1.636[0.441]$ & & \\
\hline
\end{tabular}

Not: *** ve $* *$ sirasıyla $\% 1$ ve $\% 5$ anlamlılı̆̆ göstermektedir. $\mathbf{W}_{\mathrm{LR}}$ uzun dönem asimetrik ilişkiye dair Wald testi istatistiğini, $\mathbf{W}_{\mathbf{S R}}$ kısa dönem asimetrik ilişkiye dair Wald testi istatistiğini göstermektedir. $\mathbf{F}_{\mathbf{P S S}}$ değişkenler arasındaki asimetrik eşbütünleşme ilişkisinin araştırıldığı sınır testi için $\mathrm{F}$ istatistik değerini göstermektedir. Pesaran vd. (2001)'e göre tablo kritik değerinin üst sınırı değeri \%5 anlamlılık düzeyinde 3.87'dir.

Tablo 4 finansal servetin tüketim harcamaları üzerindeki etkisine ilişkin tahmin sonuçlarını göstermektedir. İlk olarak, değişkenler arasındaki asimetrik eşbütünleşme ilişkisi test edilmektedir ${ }^{3}$. F istatistik değeri 13.774 olarak hesaplanmıştır. Bu değer, Pesaran vd. (2001) tarafından hesaplanan tablo üst değerinden (3.87) büyüktür. Dolayısıyla \%5 anlamlılık düzeyinde değişkenler arasında asimetrik eşbütünleşme ilişkisi olduğunu ifade eden alternatif hipotez kabul edilmektedir. İkinci aşamada, değişkenler arasında doğrusal olmayan ilişkilerin geçerliliğini araştırmak amacıyla Wald testi uygulanmaktadır. Elde edilen uzun dönem Wald istatistik değeri (13.625) ve kisa dönem Wald istatistik değeri (11.963) \%1 anlamlılık düzeyinde tablo değerlerinden büyüktür. Buna göre, doğrusal olmayan NARDL tahmin

\footnotetext{
${ }^{3}$ Doğrusal modeller kullanılarak gerçekleştirilen tahminlerden hareketle de sınır testi gerçekleş̧irilmiştir. Buna göre, F istatistik değeri 5.850 çıkmıştır. Sonuç olarak, doğrusal model tahmininde de değiş̧enler arasında eşbütünleşme ilişkisi olduğu sonucuna ulaşılmıştır.
} 
sonuçlarının geçerli olduğuna karar verilmektedir. Tablo 4-Panel C NARDL model tahminlerine ilişkin tanısal test istatistiklerini sunmaktadır. Buna göre modelin açıklayıcılık gücü $\left(\mathrm{R}^{2}\right.$ ve Düzeltilmiş $\mathrm{R}^{2}$ ) yeterli görülmektedir. Otokorelasyon ve değişen varyans sorununu araştırmak amacıyla gerçekleştirilen testlerin sonucu tahminlerde otokorelasyon ve değişen varyans sorunu olmadığını göstermektedir. Hata terimlerinin normal dağılımını araştırdığımız normallik testi hata terimlerinin normal dağıldığı sonucunu vermiştir. Son olarak, tahmin edilen modelde spefikasyon hatası bulunup bulunmadığını araştırdığımız Ramsey-Reset testi modelin doğru kurulduğunu göstermiştir.

Tablo 4-Panel B'de uzun dönem katsayıları yer almaktadır. Finansal servetteki artışın tüketim harcamaları üzerindeki etkisini gösteren $\mathrm{L}_{\mathrm{fs}^{+}}$katsayısı istatistiksel açıdan anlamlıdır. Buna göre, finansal servetteki \%1'lik artışın tüketim harcamaları üzerinde $\% 0.18$ artış oluşturduğu ifade edilebilir. Finansal servetteki azalışın tüketim harcamaları üzerindeki etkisini gösteren $\mathrm{L}_{\mathrm{fs}^{-}}$katsayısı da istatistiksel açıdan anlamlıdır. Buradan hareketle, uzun dönemde finansal servetteki \%1'lik azalışın tüketim harcamaları üzerinde $\% 0.21$ oranında bir azalma ortaya çıkardığı görülmektedir. Hata düzeltme modeli tahmin sonuçlarına bakılırsa, hata düzeltme katsayısı ( ect $\left._{\mathrm{t}-1}\right)$ negatif ve istatistiksel açıdan anlamlıdır. Buna göre, hata düzeltme mekanizması çalışmaktadır. Uzun dönem denge değerinden sapma oluşturacak bir şokun \%94 gibi bir hızla dengeye geldiğini göstermektedir.

Tablo 4. Finansal Servetin Tüketim Harcamalarına Etkisi NARDL Tahmin Sonuçları

\begin{tabular}{|c|c|c|c|}
\hline \multicolumn{4}{|c|}{ Panel A: Hata Düzeltme Modeli Tahmin Sonuçları } \\
\hline Değișken & Katsayl & Std. Hata & tist. \\
\hline$\Delta$ tüketim $_{t-1}$ & 0.425 & 0.10 & $3.95 * * *$ \\
\hline$\Delta$ tüketim $_{\mathrm{t}-2}$ & 0.477 & 0.12 & $3.86^{* * *}$ \\
\hline$\Delta$ tüketim $_{\mathrm{t}-3}$ & 0.598 & 0.14 & $4.24 * * *$ \\
\hline$\Delta \mathbf{f} \mathbf{s}^{+}$ & -0.009 & 0.03 & -0.27 \\
\hline$\Delta \mathbf{f} \mathbf{s}_{\mathrm{t}-1}^{+}$ & -0.065 & 0.03 & $-1.94 * *$ \\
\hline$\Delta \mathbf{f} \mathbf{s}^{-}$ & 0.089 & 0.03 & $2.57 * *$ \\
\hline$\Delta \mathbf{f} \mathbf{s}_{\mathrm{t}-1}^{-}$ & -0.119 & 0.04 & $-2.916 * * *$ \\
\hline ect $_{t-1}$ & -0.96 & 0.12 & $-7.91 * * *$ \\
\hline \multicolumn{4}{|c|}{ Panel B: Uzun Dönem Katsayıları } \\
\hline $\mathbf{L}_{\mathbf{f s}^{+}}$ & 0.184 & 0.08 & $2.19 * *$ \\
\hline $\mathbf{L}_{\mathbf{f s}} \mathbf{s}^{-}$ & 0.210 & 0.08 & $2.54 * *$ \\
\hline $\mathrm{C}$ & 6.967 & 1.145 & $6.08 * * *$ \\
\hline \multicolumn{4}{|c|}{ Panel C: Tanimlayıcı Ístatistikler } \\
\hline $\mathbf{R}^{2}$ & 0.85 & F $_{\text {PSS }}$ & $13.774 * * *$ \\
\hline Düzeltilmiş $\mathbf{R}^{2}$ & 0.79 & $\mathbf{W}_{\mathrm{LR}}$ & $13.625 * *$ \\
\hline$\chi_{\mathrm{BG}}^{2}$ & $0.252[0.779]$ & $\mathbf{W}_{\mathrm{SR}}$ & $11.963 * * *$ \\
\hline$\chi_{\text {RAMSEY }}^{2}$ & $1.922[0.068]$ & CUSUM & Durağan \\
\hline$\chi_{\mathrm{BPG}}^{2}$ & $1.118[0.392]$ & CUSUM2 & Durağan \\
\hline$\chi_{\mathrm{NOR}}^{2}$ & $1.519[0.467]$ & & \\
\hline
\end{tabular}

Not: *** ve ** sırasıyla \%1 ve \%5 anlamlılı̆̆ göstermektedir. $\mathbf{W}_{\mathbf{L R}}$ uzun dönem asimetrik ilişkiye dair Wald testi istatistiğini, $\mathbf{W}_{\mathbf{S R}}$ k1sa dönem asimetrik ilişkiye dair Wald testi istatistiğini göstermektedir. $\mathbf{F}_{\mathbf{P S S}}$ değişkenler arasındaki asimetrik eşbütünleşme ilişkisinin araştırıldığı sınır testi için F istatistik değerini göstermektedir. Pesaran vd. (2001)'e göre tablo kritik değerinin üst sınırı değeri \%5 anlamlılık düzeyinde 3.87'dir. 
Sonuç olarak, konut serveti ve finansal servetin tüketim harcamaları üzerinde etkili olduğu ifade edilebilir. Bununla birlikte, servette yaşanan artış ve azalışların tüketim harcamaları üzerindeki etkisi farklılaşmaktadır. Uzun dönemde, konut servetindeki artışın tüketim harcamaları üzerinde etkisi yok iken konut servetindeki azalışın ise tüketim harcamalarını düşürdüğü sonucu elde edilmiştir. Diğer taraftan finansal servetteki artış tüketimi artırırken finansal servetteki azalış ise tüketim harcamalarını düşürmektedir. Elde edilen sonuçlar, Türkiye ekonomisinde servetin tüketim üzerindeki etkisinin araştırıldığı çalışmalarla benzerlik taşımaktadır. Çalışmanın analiz sonuçları, konut servetindeki pozitif şokların tüketim üzerinde etkisiz olduğu dışında, konut serveti ve tüketim arasında uzun dönemde pozitif yönlü bir ilişki olduğunu göstermektedir. Ceritoğlu (2017) ve Alp ve Seven (2019) da gerçekleştirdikleri analizde aynı sonucu elde etmiştir. Finansal servetin etkisine ilişkin elde edilen pozitif yönlü etki ise, Akkoyunlu (2002) ve Güler (2012) ile benzerlik taşımaktadır. Analiz sonuçları, servetin tüketim üzerindeki etkisini nonlinear yöntemlerle araştıran Apergis ve Miller (2004); Wülfers (2017) de olduğu gibi asimetrik özellikler taşımaktadır. Bunun dışında, elde edilen sonuçlar Apergis ve Miller (2004) ile önemli bir benzerliğe sahiptir. Buna göre, hem konut hem de finansal servetteki negatif şokların tüketim harcamalarını düşürücü etkisi daha büyüktür.

\section{Sonuç}

Tüketim harcamalarının cari gelirin dışında birçok değişkenden etkilendiği uzun süredir üzerinde durulan bir konudur. Bu faktörlerin başında hanehalkının sahip olduğu servet gelmektedir. 2008 finansal krizine giden süreçte, ABD ekonomisinde yaşanan talep daralmasının konut servetinde yaşanan düşmeyle önemli bir ilişkiye sahip olduğu ifade edilebilir. Bu durum, 1950'li yıllardan itibaren ortaya konulan servet etkisinin tekrar önem kazanmasını sağlamıştır. Zira, hanehalkının servet portföyü içinde yer alan reel ve finansal unsurların değerinde yaşanacak dalgalanmaların reel ekonomi üzerinde önemli etkileri olabileceği ihtimali ortaya çıkmıştır. Türkiye ekonomisinde, 2008 finansal krizinden günümüze kadar geçen süreçte konut sektörü ve finansal piyasalarda önemli gelişmeler yaşanmıştır. Önce, uluslararası likidite düzeyi ve uygulanan ulusal ekonomi politikalarının da etkisiyle piyasalarda güçlü bir genişleme yaşanmıştır. Ardından uluslararası likidite daralması ve diğer ulusal gelişmelerin etkisiyle olumlu ekonomik hava tersine dönmüştür. $\mathrm{Bu}$ durum, konut ve diğer finansal varlıkların fiyatlarında önemli dalgalanmalar yaşanmasına neden olmuştur. $\mathrm{Bu}$ çerçevede, $\mathrm{ABD}$ ve diğer ekonomilerde geçmişte karşılaşılan olumsuz tecrübelerden hareketle, servet ve tüketim harcamaları arasındaki ilişkinin ortaya konulmasının oldukça önemli olduğu ifade edilebilir. Bu doğrultuda, çalışmanın temel amacı konut serveti ve finansal servette yaşanan değişimin tüketim harcamaları üzerindeki etkisinin ampirik olarak analiz edilmesidir.

Konut ve finansal servetteki değişimin tüketim harcamaları üzerindeki etkisini araştırmak amacıyla NARDL yöntemi kullanılmıştır. $\mathrm{Bu}$ amaçla iki model tahmin edilmiştir. İlk modelde, konut servetindeki değişimin tüketim harcamalarına etkisi tahmin edilmiştir. İkinci modelde ise, finansal servette yaşanan değişmelerin tüketim harcamaları üzerindeki etkisi araştırılmıştır. Tahminlerde, tüketim harcamalarının göstergesi olarak hanehalkı tüketim harcamaları değişkeni kullanılmıştır. Konut servetinin göstergesi olarak konut fiyatları, finansal servetin göstergesi olarak ise hisse senedi fiyatları kullanılmıştır. Analiz dönemi 2011:Q1-2019:Q4'ni içermektedir. İlk modelle gerçekleştirilen tahmin sonuçlarına bakıldığında konut serveti ve tüketim harcamaları arasında doğrusal olmayan eşbütünleşme ilişkisi olduğu sonucuna ulaşılmıştır. Uzun dönem katsayıları incelendiğinde, konut servetindeki artışın uzun dönemde tüketim harcamalarını etkilemediği ifade edilebilir. Bununla birlikte, uzun dönemde konut servetindeki \%1'lik azalışın tüketim harcamaları üzerinde \%0.32 oranında bir azalma ortaya çıkardığı görülmektedir. Başka bir ifadeyle, tüketim harcamalarında \%1'lik bir azalma olması için konut servetinin \%3.125 azalması 
gerekmektedir. Bu modelde, hata düzeltme katsayısı da beklentilerle uyumlu olarak negatif ve istatistiksel açıdan anlamlı çıkmıştır. Dolayısıyla tahmin edilen modelde hata düzeltme mekanizması çalışmaktadır. Diğer modelle gerçekleştirilen tahmin sonuçlarına bakıldığında finansal servet ve tüketim harcamaları arasında doğrusal olmayan eşbütünleşme ilişkisi olduğu görülmüştür. Uzun dönem katsayıları incelendiğinde, hem finansal servetteki artışların hem de finansal servetteki azalışların tüketim harcamaları üzerinde anlamlı etkilerinin olduğu görülmektedir. Buna göre, finansal servetteki \%1'lik artış tüketim harcamalarında \%0.18'lik bir artış oluştururken, finansal servetteki \%1'lik bir azalış tüketim harcamalarını \%0.21 düşürmektedir. Diğer bir ifadeyle, tüketim harcamalarında \%1'lik bir artış oluşması için finansal servetin \%5.55 artmas1, tüketim harcamalarında \%1'lik bir azalma olması için finansal servetin \%4.76 düşmesi gerekmektedir. Bu modelde de, hata düzeltme katsayısı beklentilerle uyumlu olarak negatif ve istatistiksel açıdan anlamlıdır. Dolayısıyla tahmin edilen modelde hata düzeltme mekanizması çalışmaktadır.

$\mathrm{Bu}$ çalışmada, literatürdeki birçok çalışmadan farklı olarak servetteki değişimin tüketim harcamaları üzerinde doğrusal olmayan etkileri olabileceği dikkate alınmıştır. Bu çerçevede gerçekleştirilen tahminler hem konut hem de finansal servetteki değişimin tüketim harcamaları üzerinde asimetrik etkilere sahip olduğunu göstermiştir. Buna ek olarak, literatürdeki ampirik sonuçların aksine, gelişmekte olan ülke grubunda yer alan Türkiye ekonomisinde yalnızca konut servetinin değil finansal servetinde tüketim harcamaları üzerinde önemli bir etkisi olduğu sonucuna ulaşılmıştır. Elde edilen ampirik sonuçlar, konut servetindeki artışın tüketim harcamaları üzerinde anlamlı bir etkisi olmasa da, konut servetindeki düşüşün tüketim harcamaları üzerinde önemli bir daralma ortaya çıkardığını göstermiştir. Bu sonuçtan hareketle konut servetinde yaşanacak azalmanın ekonomide toplam talep üzerinde güçlü ve olumsuz bir etki oluşturacağı öngörülmektedir. Bu çerçevede, konut piyasalarının hassasiyetle takip edilmesi, konut fiyatları üzerinde aşağı yönlü bask1 oluşturacak arz ve talep koşullarının kontrol edilmesi önemlidir. Bunun dışında, finansal servette yaşanan değişimin de tüketim harcamaları üzerinde etkili olduğu sonucuna ulaşılmıştır. Finansal varlık fiyatları ve tüketim harcamaları arasında tespit edilen bu etki, finansal sektör ve reel sektör arasındaki ilişkiye dair önemli ipuçları vermektedir. Bu doğrultuda, finansal piyasalardaki muhtemel istikrarsızlıkların önlenmesinin ekonomik istikrar açısından oldukça önemli olduğu ifade edilebilir. 


\section{KAYNAKÇA}

Akın, Ç. (2008). "Housing Market Characteristics and Estimation of Housing Wealth in Turkey". https://ssrn.com/abstract=1331324, (Erişim Tarihi: 19.09.2019).

Akkoyunlu, Ş. (2002). "Modelling Consumers Expenditure in Turkey, 1962-1999”. 1st OxMetrics User Conference, Faculty of Finance, Cass Business School, London.

Alp, E. ve Seven, Ü. (2019). "The Dynamics of Household Final Consumption: The Role of Wealth Channel”. Central Bank Review, 19(1): 21-32.

Aoki, K., Proudman, J. ve Vlieghe, G. (2004). "House Prices, Consumption, and Monetary Policy: A Financial Accelerator Approach". Journal of Financial Intermediation, 13(4): 414-435.

Apergis, N. ve Miller, S. M. (2004). "Consumption Asymmetry and the Stock Market: Empirical Evidence". UConn Economics Working Papers, No. 200443.

Athanassiou, E. ve Tsouma, E. (2017). "Financial and Housing Wealth Effects on Private Consumption: The Case of Greece". South-Eastern Europe Journal of Economics, 1, 63-86.

Barrell, R., Costantini, M. ve Meco, I. (2015). "Housing Wealth, Financial Wealth, and Consumption: New Evidence for Italy and the UK". International Review of Financial Analysis, 42, 316-323.

Bassanetti, A. ve Zollino, F. (2010). "The Effects of Housing and Financial Wealth on Personal Consumption: Aggregate Evidence for Italian Households”. (De Bandt O., Knetsch T., Peñalosa J. ve Zollino F. (edt)), Housing Markets in Europe kitabı içinde. Springer, Berlin, Heidelberg.

Bertaut, C.C. (2002). "Equity Prices, Household Wealth, and Consumption Growth in Foreign Industrial Countries: Wealth Effects in the 1990s". International Finance Discussion Papers, 724. Board of Governors of the Federal Reserve System.

Binay, Ş. ve Salman, F. (2008). “A Critique on Turkish Real Estate Market”. Discussion Paper No. 2008/8, Türkiye Ekonomi Kurumu.

Bonis, R. D. ve Silvestrini, A. (2012). "The Effects of Financial and Real Wealth on Consumption: New Evidence from OECD Countries”. Applied Financial Economics, 22(5): 409-425.

Borsa İstanbul. (BİST). (2019). https://www.borsaistanbul.com/, (Erişim Tarihi: 10.01.2020).

Case, K.E., Quigley, J.M. ve Shiller, R.J. (2005). “Comparing Wealth Effects: The Stock Market versus the Housing Market”. Working Papers Series, W01-004, 1-32.

Ceritoğlu, E. (2017). "The Effect of House Price Changes on Cohort Consumption in Turkey". Central Bank Review, 17, 99-110.

Ciarlone, A. (2011). "Housing Wealth Effect in Emerging Economies”. Emerging Markets Review, 12(4): 299417.

Coşkun, Y., Atasoy, B.S., Morri, G. ve Alp, E. (2018). "Wealth Effects on Household Final Consumption: Stock and Housing Market Channels". International Journal of Financial Studies, 6, 57-89.

Dvornak, N. ve Kohler, M. (2007). "Housing Wealth, Stock Market Wealth and Consumption: A Panel Analysis for Australia". The Economic Record, 83(261): 117-130.

Friedman, M. (1957). "A Theory of the Consumption Function”. Princeton University Press, Princeton.

Georgakopoulos, I. (2019). "Wealth Effects on Consumption in Malta: Evidence from Household Level Data". Applied Economics and Finance, 6(4): 28-35.

Giuliodori, M. (2005). "The Role of House Prices in the Monetary Transmission Mechanism across European Countries". Scottish Journal of Political Economy, 52(4): 519-543.

Güler, M.H. (2012). "Housing Wealth Effects Mechanism and the Monetary Policy Transmission in Turkey". Yayımlanmamış Doktora Tezi, University of North Carolina.

Hamburg, B., Hoffmann, M. ve Keller, J. (2008). "Consumption, wealth and business cycles in Germany". Empirical Economics, 34, 451-476.

Helander, M. (2014). "Estimating Wealth Effects on Consumption in Finland". Statistics Finland Working Papers, 4, 1-55.

Hui, E., Zheng, X. ve Zuo, W. (2012). "Housing Wealth, Stock Wealth and Consumption Expenditure: A Dynamic Analysis for Hong Kong”. Property Management, 30(5): 435-448.

Kengne, B.D., Gupta, R. ve Bittencourt, M. (2012). "The Impact of House Prices on Consumption in South Africa: Evidence from Provincial-Level Panel VARs". Housing Studies, 28(8): 1133-1154.

Ludwig, A. ve Slok, T. (2004). "The Relationship between Stock Prices, House Prices and Consumption in OECD Countries". The B.E. Journal of Macroeconomics, 4(1): 1-28.

Márquez, E., Martínez-Cañete, A. ve Pérez-Soba, I. (2013). "Wealth Shocks, Credit Conditions and Asymmetric Consumption”. Economic Modelling, 33, 357-366.

Marzabal, O.R. ve Junior, V.M.F. (2016). “The Wealth Effect in the Eurozone”. Panoeconomicus, 63(1): 87-112. Milcheva, S. ve Sebastian, S. (2010). "Housing Channels of Monetary Policy Transmission in European Industrial and Transition Countries". 17th Annual European Real Estate Society Conference, Milano.

Modigliani, F. ve Brumberg, R. (1954). "Utility Analysis and the Consumption Function: An Interpretation of Cross-Section Data”. The MIT Press (2005), Cambridge. 
Özer, Y.B. ve Tang, K.K. (2009). "An Empirical Analysis of Financial and Housing Wealth Effects on Consumption in Turkey”. MRG Discussion Paper Series, 2809. School of Economics, University of Queensland, Australia.

Peltonen, T.A., Sousa, R.M. ve Vansteenkiste, I.S. (2012). "Wealth Effects in Emerging Market Economies". International Review of Economics \& Finance, 24, 155-166.

Pesaran, M.H., Shin, Y. ve Smith, R.J. (2001). "Bound Testing Approaches to the Analysis of Level Relationships". Journal of Applied Econometrics, 16(3): 289-326.

Shen, X., Holmes, M.J. ve Lim, S. (2014). "Wealth Effects and Consumption: A Panel VAR Approach". International Review of Applied Economics, 29(2): 221-237.

Shin, Y., Yu, B. ve Greenwood-Nimmo, M. (2014). "Modelling Asymmetric Cointegration and Dynamic Multipliers in a Nonlinear ARDL Framework". Festschrift in Honor of Peter Schmidt: Econometric Methods and Applications. (eds. by R. Sickels and W. Horrace) Springer, pp. 281-314.

Singh, B. (2012). "How Important is the Stock Market Wealth Effect on Consumption in India?". Empirical Economics, 42(3): 915-927.

Slacalek, J. (2009). "What Drives Personal Consumption? The Role of Housing and Financial Wealth". The B.E. Journal of Macroeconomics, 9(1): 1935-1690.

Sonje, A.A., Casni, A.C. ve Vizek, M. (2014). "The Effect of Housing and Stock Market Wealth on Consumption in Emerging and Developed Countries". Economic Systems, 38(3): 433-450.

Sousa, R.M. (2009). "Wealth Effects on Consumption Evidence from the Euro Area". ECB Working Paper Series, No. 1050. European Central Bank.

Türkiye Cumhuriyet Merkez Bankası (TCMB). (2019). https://www.tcmb.gov.tr/, (Erişim Tarihi: 10.01.2020).

Türkiye İstatistik Kurumu (TÜİK). (2019). https://www.tuik.gov.tr/, (Erişim Tarihi: 10.01.2020).

Winkler, S. (2016). "Empirical Evidence of Wealth Effects on Consumption". 34th IARIW General Conference, Dresden, Germany.

Wülfers, J.F. (2017). "Asymmetric Wealth Effects on Consumption: A Threshold Cointegration Approach on Swedish Households". Yayımlanmamış Yüksek Lisans Tezi, Lund University. 